\title{
浅い球形款のランダム加振に対する非線形応答の解析* \\ An Analytical Study of Nonlinear Response of Shallow Spherical Shells to Random Excitation
}

\author{
小林繁 夫**.甲 斐 高 志*** \\ Shigeo KobayashI, Takashi KaI \\ 末 益 博 志**** \\ and Hiroshi Suemasu
}

\begin{abstract}
Probabilistic properties of nonlinear response of shallow spherical shells with clamped edges to random excitation are analy tically investigated with the aid of simulation method in order to disclose the effects of the curvature on the acoustic fatigue lives. The deflection is expressed as a series expansion of the axisymmetric normal modes of vibration, and the nonlinear equations of vibration for the generalized coordinates are derived. The equations in the three modes approximation are numerically solved by NEW. MARK's $\beta$ method for random excitation forces. The probabilistic quantities of the response are calculated for various combinations of the pressure level and the curvature. The results have revealed the following properties. At high pressure levels the large amplitude vibration includes the snap-through buckling. The change of vibrational mode occurs during the snap-through. At very high pressure levels the probabilistic properties of the center deflection approach those of the flat panel. The fatigue lives of the shells can be shorter than those of the flat plate when the vibration includes the snap-through. The fatigue properties cannot be explained by the mean value and the standard deviation of the stress but explained by its probability density function (PDF), because the PDF is quite different from the Gaussian distribution. Then the static equilibrium load-deflection curves are calculated from the same discretized nonlinear equations and show good agreement with the previous results.
\end{abstract}

\section{1. 緒豆}

著者らは, 航空機外板パネルの音響痖労問題解明を 目的として，ランダム加振に対するパネルの非線形振 動応答ならびに疲労寿命についてシミュレーション法

\footnotetext{
*昭和 55 年 7 月 18 日，第 22 回構造強度に関する請演会 厄発表. 昭和 57 年 3 月 26 日原稿受理

** 東京大学工学部航空学科

*** 航空宇宙技術研究所機体二部

**** 東京大学工学部境界領城研究施設
}

による解析研究を行ってきたか，その一環として浅い 球形款について研究を行ったものである，この問題に 関しては，これまで著者の一人が 1 自由度近似を用い て Fokker PLANCK の方程式の解を求める方法により その特性について議論しだ 以外には，研究論文は見 られない，1自由度近似では不十分であるので，多自 由度近仪し，その解をシミェレーション法により求 め，非線形振動応答特性およひ疲労寿命に対する殸の 深さと音圧の大きさの関連した影響を明らかにしよう としたあのである。なおこの問題は，款構造力学で注 目されている問題である“一様外圧による浅い球款の 座屈”と関連した問題であり，座屈域も含む振動なの で，振動特性の理解を助けるため，飛移り座屈域を含 む静的平衡曲線を計算し，あわせて計算精度の目安と した.

\section{2. 非線形振動方程式}

第 1 図のような浅い球形殸の形状を近似的に

$$
Z(r)=\left(a^{2}-r^{2}\right) /(2 R)
$$

で表し，浅い殼の理論を用いて解析する，殼の㳭さを 表すのに板厚 $h$ で割った無次元形状パラメータ

$$
H=Z(0) / h=a^{2} /(2 R h)
$$

を用いる．外力は一様分布圧力とし，变形は軸対称変 形のみを考える，境界条件は $r=a$ で周辺固定，すな わち

$$
\begin{aligned}
& w=\frac{\partial w}{\partial r}=0 \\
& u=0
\end{aligned}
$$

とする. 変位 $u, w$ の方向を第 1 図に示した.

応力 $\{\sigma\}^{\mathrm{T}}=\left\lfloor\sigma_{\rho}, \sigma_{\theta}\right\rfloor$ 之歪 $\{\varepsilon\}^{\mathbf{T}}=\left\lfloor\varepsilon_{\rho}, \varepsilon_{\theta}\right\rfloor$ との間に

$$
\begin{aligned}
& \{\sigma\}=\left\{\sigma^{\circ}\right\}+\left\{\sigma^{\vee}\right\} \\
& \left\{\sigma^{\circ}\right\}=[B]\{\varepsilon] \\
& \left\{\sigma^{*}\right\}=\frac{\eta}{\omega_{\mathbb{R}}}[B] \frac{\partial}{\partial t}\{\varepsilon\} \\
& {[B]=\frac{E}{1-\nu^{2}}\left[\begin{array}{ll}
1 & \nu \\
\nu & 1
\end{array}\right]}
\end{aligned}
$$

なる線形粘弾性の関係が成り立つと考える，ととで， 
添字 $\rho, \theta$ はそれぞれ $\rho$ 方向，円周方向を表し， $E$ は

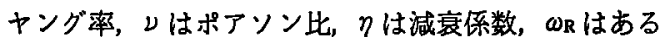
基準振動数（後述）である.

軸対称な有限変形の場合, 歪と変位の関係は

$$
\begin{aligned}
& \varepsilon_{p}=\varepsilon_{p 0}-\zeta \frac{\partial^{2} w}{\partial r^{2}}, \quad \varepsilon_{\theta}=\varepsilon_{\theta 0}-\frac{\zeta}{r} \frac{\partial w}{\partial r} \\
& \varepsilon_{p 0}=\frac{\partial u_{0}}{\partial r}+\frac{1}{2}\left(\frac{\partial w}{\partial r}\right)^{2}-\frac{r}{R} \frac{\partial w}{\partial r}, \quad \varepsilon_{\theta 0}=\frac{u_{0}}{r}
\end{aligned}
$$

で与えられる．ここでらは中央面の法線方向にとった 座標, 添字 0 は中央面の値を表す。

$r$ 方向の力の平衡方程式は， $r$ 方向の慣性力を省略 すると，

$$
\frac{\partial \sigma_{\rho 0}}{\partial r}+\frac{\sigma_{\rho 0}-\sigma_{\theta 0}}{r}=0
$$

その弾性成分 $\sigma_{\theta 0}{ }^{\circ}, \sigma_{\theta 0}{ }^{*}$ について

$$
\sigma_{p 0} \mathrm{e}=\frac{\chi}{r}, \quad \sigma_{\theta 0} \mathrm{e}=\frac{\partial \chi}{\partial r}
$$

なる応力関数 $\chi$ を導く之, (7) と（6)の関保から, (11) 式をみたすことがわかる，z方向の力の平衡方程式は $\sigma_{p 0}$ を $\chi$ を用いて表し

$$
\begin{aligned}
& D \Delta \Delta\left(w+\frac{\eta}{\omega_{\mathrm{R}}} \frac{\partial w}{\partial t}\right)-\frac{h}{r} \frac{\partial}{\partial r}\left\{\left(\chi+\frac{\eta}{\omega_{\mathrm{R}}} \frac{\partial \chi}{\partial t}\right)\right. \\
& \left.\times\left(\frac{\partial w}{\partial r}-\frac{r}{R}\right)\right\}+\rho_{\mathrm{m}} h \frac{\partial^{2} w}{\partial t^{2}}=p(t)
\end{aligned}
$$

となる. とてで

$$
D=\frac{E h^{3}}{12\left(1-\nu^{2}\right)}, \quad \Delta=\frac{\partial^{2}}{\partial r^{2}}+\frac{1}{r} \frac{\partial}{\partial r}
$$

$\rho_{\mathrm{m}}$ は材料密度， $p(t)$ は一様王力 $(z$ 方向正)である。 一方(10)式加ら $u_{0}$ を消去して，(6) と(12) を用い， 適合条件式

$$
r \frac{\partial}{\partial r}\left\{\frac{1}{r} \frac{\partial}{\partial r}(r \chi)\right\}+E\left\{\frac{1}{2}\left(\frac{\partial w}{\partial r}\right)^{2}-\frac{r}{R} \frac{\partial w}{\partial r}\right\}=0
$$

加導加れる．(13)，(14)式が粘弾性勃果を考虑してw

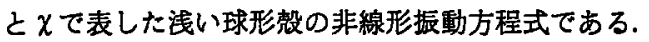

(14)式の $\chi$ は，2 回皘分により導かれる特解に，斉 次解 $C_{0} r$ を付け加え，（4）式の境界条件 $u_{0}=0$ 加ら 導かれる $(\partial \chi / \partial r-\nu \chi / r)_{r=a}=0$ に代入してCo の值を

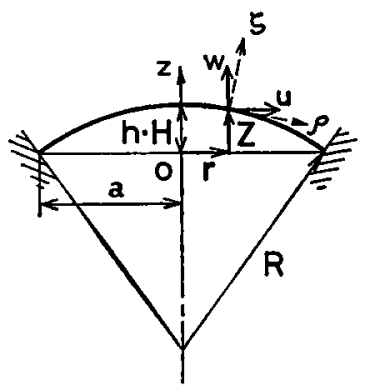

第1図 浅い球形憘と座標
決めると

$$
\begin{aligned}
\chi(r)= & \frac{E r}{4} \int_{r}^{a} \frac{1}{r_{1}}\left(\frac{\partial w}{\partial r_{1}}\right)^{2} d r_{1}+\frac{E}{r}\left[\frac{1}{R} \int_{0}^{r} r_{1} w d r_{1}\right. \\
& \left.+\frac{1}{4} \int_{0}^{r} r_{1}\left(\frac{\partial w}{\partial r_{1}}\right)^{2} d r_{1}\right] \\
& +\frac{(1+\nu) E r_{1}}{(1-\nu) a^{2}}\left[\frac{1}{R} \int_{0}^{a} r_{1} w d r_{1}\right. \\
& \left.+\frac{1}{4} \int_{0}^{a} r_{1}\left(\frac{\partial w}{\partial r_{1}}\right)^{2} d r_{1}\right]
\end{aligned}
$$

となることが導かれる，との計算には(3)式の条件を 用いている.

(15)式を(13)式に代入するとwのみで書き表された 非線形振動方程式が得られる. その方程式で $\eta=p(t)$ $=0$ とし, $w$ の 2 次以上の項を省略して導かれる非湜 衰の線形振動方程式に

$$
w(r, t)=\phi(r) \sin \omega t
$$

を代入すると， $\phi$ が満たすへき方程式

$$
\begin{aligned}
& \Delta \Delta \phi-\alpha^{4} \phi+K \int_{0}^{a} r \phi d r=0 \\
& \alpha^{4}=h\left(\omega^{2} \rho_{\mathrm{m}}-E / R^{2}\right) / D \\
& K=24[(1+\nu) /(R h a)]^{2}
\end{aligned}
$$

加導加れる.（17)式の斉次方程式の四つの基本解のj ち $Y_{0}(\alpha r), K_{0}(\alpha r)$ は $r=0$ で特異性をすつので捨て, 特解は定数となるゆえ，これを $C_{0}$ と記すと，(17)式 の一般解は

$$
\phi=C_{1} J_{0}(\alpha r)+C_{2} I_{0}(\alpha r)+C_{0}
$$

と表される. とれを(17)式代入して定数 $C_{0}$ を $C_{1}$ と $C_{2}$ で表す関係式か導かれる. そてで $r=a$ で $\phi=$ $d \phi / d r=0$ はる境界条件 (3) 亿代入して得られる $C_{1}$ と $C_{2}$ の斉次連立方程式の $C_{1}, C_{2}$ の係数の行列式を 零之おいて固有振動数方程式

$$
\frac{J_{0}(\alpha a)}{J_{1}(\alpha a)}+\frac{I_{0}(\alpha a)}{I_{1}(\alpha a)}+\frac{2 a K}{\alpha\left(\alpha^{4}-K a^{2} / 2\right)}=0
$$

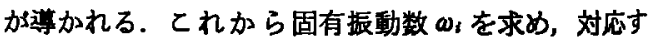
ろ固有振動モード

$$
\phi_{l}=A_{i}\left[\frac{J_{0}\left(\alpha_{i} r\right)}{J_{1}\left(\alpha_{i} a\right)}+\frac{I_{0}\left(\alpha_{i} r\right)}{I_{1}\left(\alpha_{1} a\right)}+\frac{2 a K}{\alpha_{1}\left(\alpha_{i}^{4}-K a^{2} / 2\right)}\right]
$$

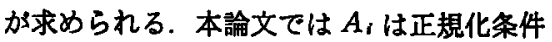

$$
2 \pi \int_{0}^{a} r \phi_{i}^{2} d r=\pi a^{2}
$$

加ら決まる定数である. $H=0,2.5,5,10$ の 4 通り の殻の 3 次までの固有振動数，固有振動モードを第 2 図に示した。ここで

$$
\begin{gathered}
\omega_{\mathrm{R}}=\frac{h}{a^{2}} \sqrt{\frac{E}{\rho_{\mathrm{m}}}} \\
\text { この固有振動モード } \phi_{i}(r) \text { を用いて } \\
w(r, t)=h \sum_{i=1}^{N} W_{i}(t) \phi_{i}(r)
\end{gathered}
$$


$H=0$
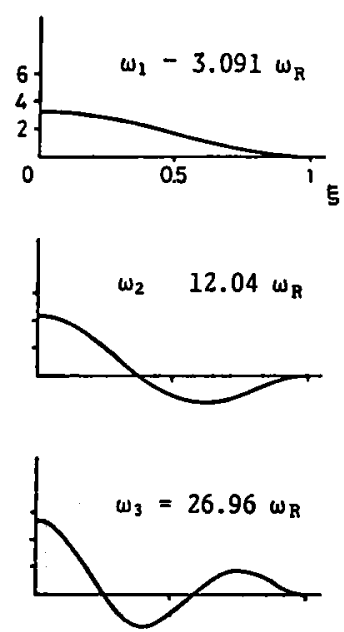

$H=2.5$
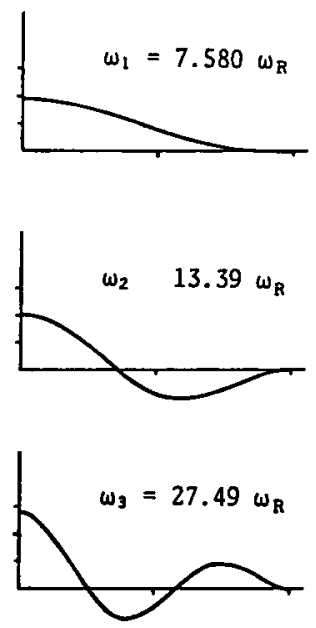
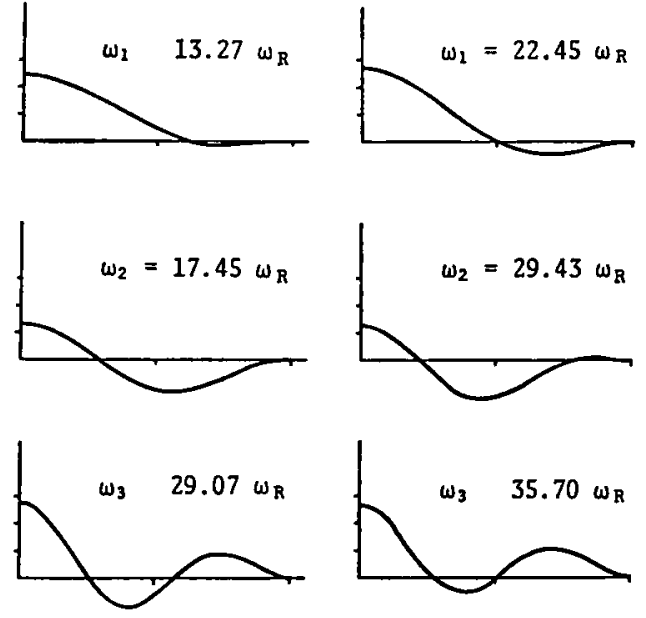

第 2 图固有振娌数と固有振動モード

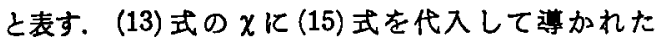
$\boldsymbol{w}(r, t)$ のみの非線形振動方程式に(24)式を代入して GALERKIN 法を商用すると非線形連立微分方程式

$$
\begin{aligned}
& \ddot{W}_{\imath}+B_{\imath}\left(W_{\imath}+\eta \dot{W}_{l}\right)+\sum_{i} \sum_{j} C_{i j l} W_{l} W_{l} \\
& \quad+\eta \sum_{i} \sum_{j} D_{i j l} \dot{W}_{i} W_{j}+\sum_{i} \sum_{j} \sum_{k} E_{i j k l}\left(W_{i} W_{l} W_{k}\right. \\
& \left.\quad+2 \eta \dot{W}_{\imath} W_{j} W_{k}\right)=2 f \psi_{l}(1) \quad(l=1,2, \cdots)
\end{aligned}
$$

が得られる.ただし

$$
\begin{aligned}
& f=(p(\tau) / E)(h / a)^{4} \\
& \tau=\omega_{\mathrm{R}} t, \quad \xi=r / a \\
& B_{\| l}=\frac{1}{6\left(1-\nu^{2}\right)} \int_{0}^{1}\left(\frac{1}{\xi} \phi_{t^{\prime}} \phi_{j^{\prime}}+\xi \phi_{i}^{\prime \prime} \phi_{j^{\prime \prime}}\right) d \xi \\
& +8 H^{2}\left\{\int_{0}^{1} \xi \phi_{i} \phi_{j} d \xi+2 \frac{1+\nu}{1-\nu} \phi_{i}(1) \psi_{l}(1)\right\} \\
& C_{i j l}=2 H\left[\frac{1+\nu}{1-\nu} T_{i s}(1) \psi_{l}(1)+G_{i j l}\right. \\
& \left.+2\left\{\frac{1+\nu}{1-\nu} T_{\imath}(1) \psi_{l}(1)+G_{u}\right\}\right] \\
& D_{i \jmath l}=4 H\left[\frac{1+\nu}{1-\nu} T_{i j}(1) \phi_{l}(1)+G_{i, l}\right. \\
& \left.+\frac{1+\nu}{1-\nu} T_{\mu}(1) \psi_{l}(1)+G_{\mu}\right] \\
& E_{r j k l}=\frac{1}{2}\left[\frac{1+\nu}{1-\nu} T_{i j}(1) T_{A l}(1)+H_{i j k l}\right] \\
& \psi_{i}(x)=\int_{0}^{x} \xi \phi_{i} d \xi \\
& T_{1 j}(x)=\int_{0}^{x} \xi \phi_{\gamma^{\prime}} \phi_{j^{\prime}} d \xi \\
& G_{i J l}=\int_{0}^{1} \frac{1}{\xi} \phi_{l^{\prime}} \phi_{J^{\prime}} \psi_{l} d \xi
\end{aligned}
$$

$$
H_{i j k l}=\int_{0}^{1}\left(\frac{1}{\xi} \phi_{i^{\prime}} \phi_{j^{\prime}} T_{k \imath}+\frac{1}{\xi} \phi_{k^{\prime}} \phi_{\imath^{\prime}} T_{\imath \jmath}\right) d \xi
$$

とおいたもので（・）はてによる微分，(')は光によ る微分を表わす. (28) 式中の $\phi$ は (22) 式の $r$ $a \xi$ を 代入したものである.

注目する応力值として $r=r$ の点におりる上下両表 面の $\rho$ 方向応力の弾性成分を求めておく.一般に $(r, \zeta)$ の点における $\rho$ 方向応力の弾性成分 $\sigma_{\rho}{ }^{\bullet}$ は $(6),(9)$,

(12)式を用いて

$$
\sigma_{p}=\frac{\chi}{r}-\frac{E}{1-\nu^{2}} \zeta\left(\frac{\partial^{2} w}{\partial r^{2}}+\frac{\nu}{r} \frac{\partial w}{\partial r}\right)
$$

と表される. $\chi に(15)$ 式を，wに(24)式を代入し， $\zeta=$ $\pm h / 2$ なる上下両表面での応力を $E(h / a)^{2}$ で割り無次 元化して表すと

$$
\begin{aligned}
\frac{\left(\sigma_{\rho}^{\mathrm{e}}\right)_{\zeta- \pm n / 2}}{E(h / a)^{2}}= & \left\{\begin{array}{l}
S_{U} \\
S_{\mathrm{L}}
\end{array}\right\}=\sum_{i}\left[2 H\left\{\frac{1+\nu}{1-\nu} \phi_{i}(1)+\frac{1}{\xi^{2}} \phi_{i}(\xi)\right\}\right. \\
& \left.\mp \frac{1}{2\left(1-\nu^{2}\right)}\left\{\phi_{i^{\prime \prime}}(\xi)+\frac{\nu}{\xi} \phi_{i^{\prime}}(\xi)\right\}\right] W_{i} \\
& +\frac{1}{4} \sum_{i} \sum_{j}\left[\int_{\xi}^{1} \frac{1}{\xi} \phi_{i^{\prime}} \phi_{j^{\prime}} d \xi\right. \\
& \left.+\frac{1+\nu}{1-\nu} T_{i j}(1)+\frac{1}{\xi^{2}} T_{i j}(\xi)\right] W_{i} W_{,}
\end{aligned}
$$

\section{3. 静的平衡曲線}

前節で得られた㧐動方程式 (25) 式において，慣性項 と粘性項とを省略すれば，静的な場合の平衡方程式

$B_{\imath} W_{l}+\sum_{i} \sum_{j} C_{i j l} W_{i} W_{j}+\sum_{i} \sum_{j} \sum_{k} E_{i j k l} W_{i} W_{j} W_{k}$

$$
=2 f \phi_{l}(1) \quad(l=1,2, \cdots)
$$

が得られる. この方程式を，荷重増分法と変位增分法 
とを組み合わせて解き2），静的平衡曲楾（第 3 困）を得 た. 横軸 $W$ は中央点の変位を板厚で割って無次元化 したものである. 図中 dof は自由度 (degree of freedom) を表す.

$H=0,2.5 ， 5$ の 3 個の殼において，1 次から 5 次 までの固有振動モードを用いた 5 自由度による計算結 果は文献 3)に示されている結果上よく一致している. $H=10$ の場合，因示は省略したが， 3 自由度による 計算結果は 5 自由度によるそれと若干異なっている。 $H=10$ の殻は文献の中に形状パラメータが一致する 殼がないがそれれに近いあの゙2と 5 自由度による計算 結果は似た傾向を示しており，Wについては 5 自由 度でほほ収束していると考えられる。

次に，座届荷重と形状パラメータ $\lambda$ との関係を第 4 因に示した。なお， $\lambda$ と $H$ の関係は

$$
\lambda=2\left[3\left(1-\nu^{2}\right)\right]^{1 / 4} V \bar{H}
$$

で与えられる，図中の実線は，BUDIANSKY Y)，WEINITSCHKE ${ }^{5}$, THURSTON ${ }^{6)}$ らによって求められた対称変 形する浅い球形殼の座屈荷重 $f_{\mathrm{cr}}$ の曲線であるか，本 解析法による 5 自由度の計算結果はよく一致してい る. $f_{\mathrm{cl}}$ は古典理論值である.

第 3，4四加ら，変形を殼の線形振動モードで展開 することの保証加得られたものと考えられる，第 3 困 から， $H=5$ までは 3 自由度近似でほほ収束している と考えられるので，次節以降の振動応答のシミュレー ション計算は 3 自由度で行った。

平衡状態にあるときの王力と固定辺上下両面の $\rho$ 方

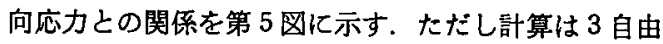
度で行ったあのである. $H=5$ の殼では飛び移りに伴 って曲線がループを描く.

\section{4. シミュレーション法によるランダム}

\section{振動応答の計算}

ランダムな外力 $f(\tau)$ か，平均 $E[f(\tau)]=0$ で $\Phi_{\mathrm{II}}(\omega)$ なるパワースペクトル密度 $(\mathrm{PSD})$ をあつガウス ランダム過程の場合を取り扱う. 本論文では第6図に 示すような有限帯域幅のホワイトノイズを报うので, この外力の大きさを表す無次元パラメータとして，そ の一定部分の $\Phi_{I}$ の值から導加る

$$
Q=\sqrt{\Phi_{\mathrm{H}} / \eta}
$$

を用いることにし， $Q=25,50,100 ， 200 ， 400$ の 5 通りの場合について計算した。

ランダムな外力の作り方は文献 7) と同じである. 乙の外力 $f(\tau)$ に対する応答は NEWMARK $の \beta$ 法 $(\beta$ $=1 / 6)$ を用いて 3 次の固有振動モードまでを用いた 3 自由度近似の連立非線形振動方程式 (25) 式を解いて求 めた. それらの結果から中央点変位 $W=w(0, t) / h$,

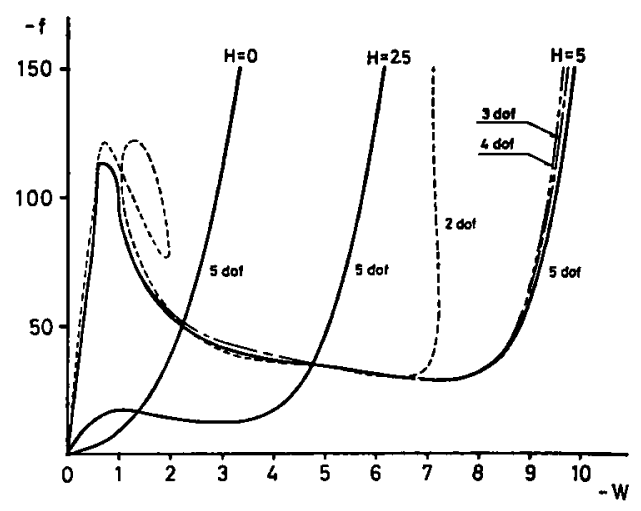

第3 因 静的平衡曲線

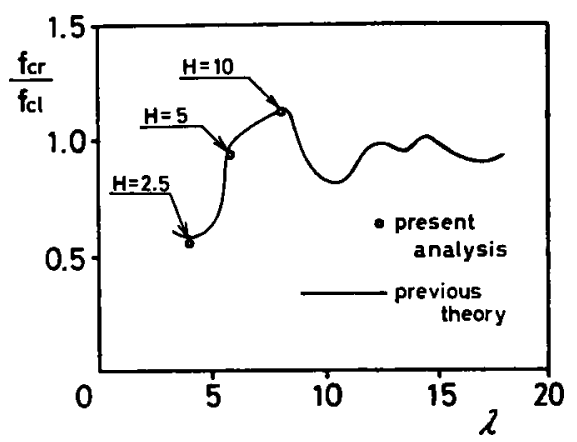

第4図座届荷重と形状パラメータイとの関保

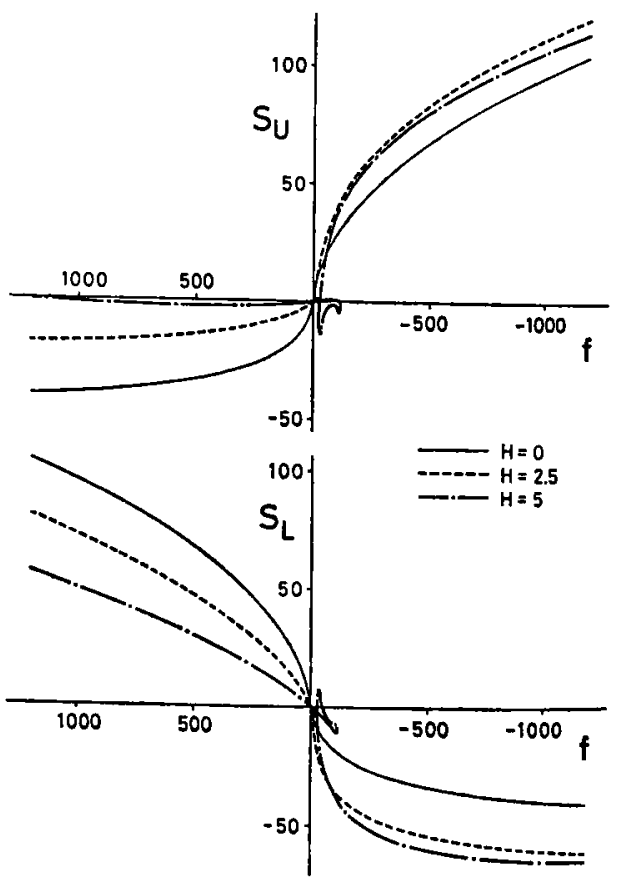

第 5 因 固定边上面応力 $S_{U}$ およひ不面応力 $S_{L}$ と圧 力 $f$ との関係 ( 3 自由度) 


\begin{tabular}{ll} 
& 第 1 表 \\
\hline$h$ & $0.5 \mathrm{~mm}$ \\
$a$ & $100 \mathrm{~mm}$ \\
$E$ & $7,000 \mathrm{~kg} / \mathrm{mm}^{2}$ \\
$\rho_{\mathrm{m}}$ & $2.8 \times 10^{-10} \mathrm{~kg} \cdot \mathrm{sec}^{2} / \mathrm{mm}^{4}$ \\
$\eta$ & $8.088 \times 10^{-4}$ \\
\hline
\end{tabular}

第2表 Qと1 Hz あたりの SPL との関係

\begin{tabular}{cccccc}
\hline$Q$ & 25 & 50 & 100 & 200 & 400 \\
\hline SPL(dB) & 134.7 & 140.7 & 146.7 & 152.7 & 158.7 \\
\hline
\end{tabular}

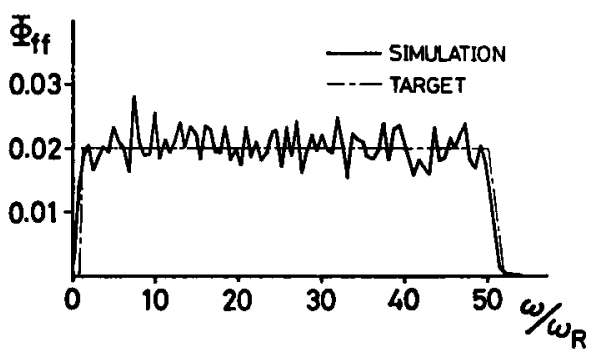

第6図 外力 $f(\tau)$ のパワースペクトル密度 (PSD)

固定辺上下両面の $\rho$ 方向応力 $S_{\mathrm{U}}, S_{\mathrm{L}}$ を計算し, 種々 の統計量を文献 7)の方式に従って求めた。 ちなみに, シミュレーションは $\Delta \tau=0.01$ で行い，1 サンプルは 1,024 個の時刻点からなり，64サンプルのデータから 統計量を計算した．との統計量をもってての系の確率

\section{量とした。}

後で疲労寿命計算の際に必要となる系の数值モデル を第 1 表に示す. 減衰係数 $\eta$ は， 月板 $(H=0)$ の 1 次 固有振動数 $\omega_{1}=3.091 \omega_{\mathrm{R}}$ に対して, $\left(\omega_{1} / \omega_{\mathrm{R}}\right) \eta$ がシ ラルミン板等の構造減衰係数 0.0025 之等しくなるよ うに定めた值である. この場合の $Q$ 之 $1 \mathrm{~Hz}$ あたりの 音匠レベル (SPL: Sound Pressure Level) との関係 を第 2 表に示す。

外力 $f(\tau)$ のPSD を第 6 図に示す.一点鎖線で示 す target の有限帯域幅ホワイトノイズをよく近似し ていると考えられる.

$W, S_{\mathrm{U}}, S_{\mathrm{L}}$ の平均 (mean) および標準偏差 (SD: standard deviation) を第 3 表俰示す，WのSDに注 目すると， $Q=25$ では $H$ が大きくなるにつれて小さ くなるが，Q=50では $H=2.5$ の SD は $H=0$ のそ れにかなり近ついており，Q=100では $H=2.5$ が最 も大きくなる．さらに $Q=200$ では $H=5$ が最大とな り， $Q=400$ では $H=10$ の SD 6他之同じオーダー になっている，てのととからＱQ=25では曲率をつけ たことによって剛性加高まるか，Q $Q$ か 50 を越える場 合は曲率をつけたためにかえって大振幅で振動するて とがあるというととがわかる.

以下，W， $S_{\mathrm{v}}, S_{\mathrm{L}}$ のピークの確率密度関数 (PDF : probability density function) のQに対する変化につ いて述べる. 都合上， $Q$ は $25 ， 100 ４ 00$ の

第 3 表 $W, S_{U}, S_{\mathrm{L}}$ の平均と標準偏差

\begin{tabular}{|c|c|c|c|c|c|c|c|}
\hline \multirow{2}{*}{$Q$} & \multirow{2}{*}{$H$} & \multicolumn{2}{|c|}{$W$} & \multicolumn{2}{|c|}{$S_{\mathrm{U}}$} & \multicolumn{2}{|c|}{$S_{\mathrm{L}}$} \\
\hline & & Mean & $\mathrm{SD}$ & Mean & SD & Mean & $\mathrm{SD}$ \\
\hline \multirow{4}{*}{25} & 0 & $-6.52_{-2^{*}}$ & 1.20 & 8. $29_{-1}$ & 7.06 & 7.79_, & 7.06 \\
\hline & 2.5 & $-3.42_{-1}$ & 7. $72_{-1}$ & $-1.60_{-1}$ & 2.94 & $-3.37_{-1}$ & 3.87 \\
\hline & 5 & $-4.18_{-2}$ & $2.48_{-1}$ & $-4.76_{-3}$ & 1.77 & -2.28 & 2. 24 \\
\hline & 10 & -3.53 & $7.11_{-3}$ & $-6.48_{-}$ & 1.09 & 4. 99 & 1.06 \\
\hline \multirow{4}{*}{50} & 0 & 2. 74-s & 1.75 & 1.89 & 1. $16_{+1}$ & 1.90 & 1. $15_{+1}$ \\
\hline & 2.5 & -1.24 & 1.66 & 2.02 & 7.38 & -2.87 & 8.45 \\
\hline & 5 & $-1.70_{-1}$ & 5. $34_{-1}$ & $-1.80_{-1}$ & 3.78 & $-1.00_{-1}$ & 5.08 \\
\hline & 10 & $-1.41_{-1}$ & $1.43-1$ & -2.65. & 2.18 & $2.17_{-1}$ & 2.11 \\
\hline \multirow{4}{*}{100} & 0 & 7.18_, & 2.47 & 4.10 & $1.84_{+1}$ & 4.14 & $1.84_{+1}$ \\
\hline & 2.5 & -1.96 & 2.49 & 8.57 & 1. $79_{+1}$ & -5.56 & 1. $54_{+1}$ \\
\hline & 5 & -1.07 & 1.87 & -1.79 & 8.83 & 1.07 & 9.55 \\
\hline & 10 & $-5.61_{-3}$ & $2.97_{-1}$ & $-1.23-1$ & 4. 32 & $1.13_{-1}$ & 4.14 \\
\hline \multirow{4}{*}{200} & 0 & 4. 97 & 3. 32 & 7.95 & $2.80_{+1}$ & 7.74 & 2. $81_{+1}$ \\
\hline & 2.5 & -2.35 & 3. 38 & $1.66_{+1}$ & 2. $91_{+1}$ & -5.72 & 2. $38_{+1}$ \\
\hline & 5 & -4.14 & 3.64 & 2.92 & 2. $08_{+1}$ & $-4.56_{-1}$ & $1.87_{+1}$ \\
\hline & 10 & $-2.65_{-1}$ & $7.40_{-1}$ & $-6.66_{-1}$ & 8.12 & $7.60_{-1}$ & 7.67 \\
\hline \multirow{4}{*}{400} & 0 & -8.20. & 4. 34 & 1. $36_{+1}$ & $4.06+1$ & 1. $40_{+1}$ & 4. $03_{+1}$ \\
\hline & 2.5 & -2.27 & 4. 11 & $2.38_{+1}$ & $3.88_{+1}$ & -4.94 & 3. $35_{+1}$ \\
\hline & 5 & -4.71 & 4.52 & 1. $42_{+1}$ & 3. $24_{+1}$ & -5.52 & 3. $23_{+1}$ \\
\hline & 10 & -1.49 & 2. 36 & -2.77 & $1.77_{+1}$ & 8.81 & 3. $22+1$ \\
\hline
\end{tabular}

$*-6.52_{-1}=-6.52 \times 10^{-1}$ 


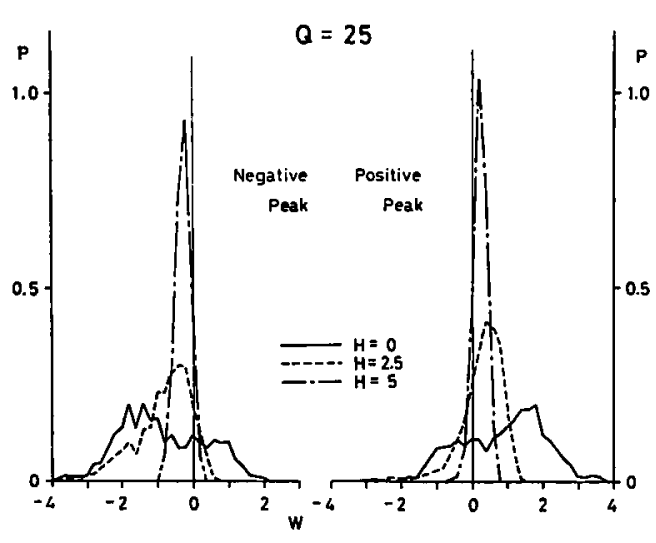

第7図 中央点変位 $W$ のピークの確率密度関数 (PDF) $Q=25$ の場合

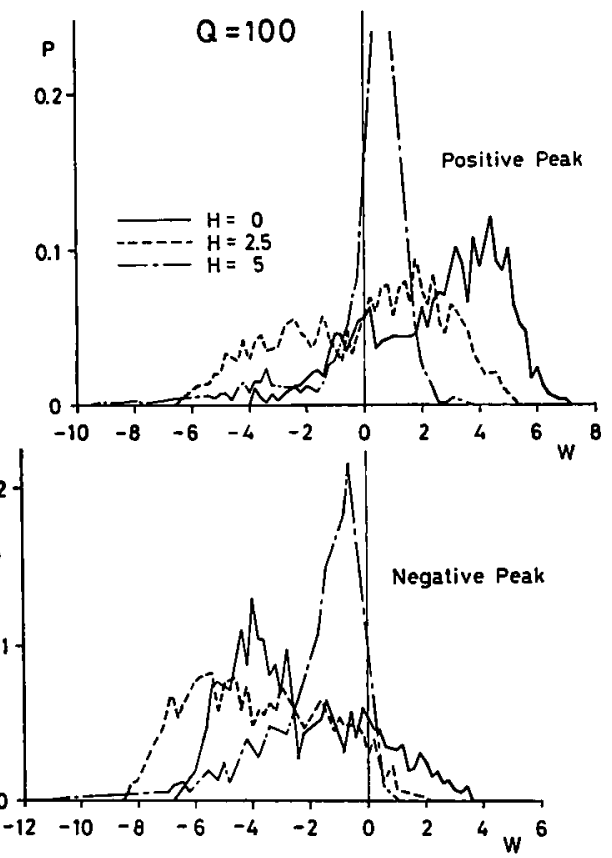

第 8 図中央点変位 $W$ のピークの確率密度関数 (PDF) $Q=100$ の場合

通りについて示す.

まずのピークの PDF の結果について考察する. $Q=25$ (第 7 図) では，H が大きくなるにつれて分布 の幅が狭くなるので，曲率をつけることによる用性の 増加の勃果があることがわかる. また， $H=2.5$ の正 のピークは大部分が正側に存在しているか，負側にも

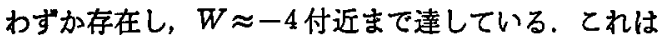
静的平衡曲線（第 3 図）の飛び移り先に対応しており， 飛ひ移りに伴う変形形状の変化のために生じた現象之 考えられる.

$Q=100$ (第 8 図) では，各 $H$ とす，分布の幅が広く なり，H=2.5，5では飛び移り座届をともなう大振
幅振動が起きているととがわかる. $H=2.5$ の場合, 分布の幅が広がり，ほとんどすべての振動が飛び移り を起てしていると考えられる. また $W<0$ 側に生し る正のピークの存在確率が $W>0$ 側と同じくらいに なっているか，これは飛び移りに伴い高次のモードが 誘起されて生ずる変形形状の変化住対応していると考 えられる， $H=5$ の場合，正負両ピークの $W<0$ の側 の裾が長く伸びており，飛び移り現象を生じる確率が 大きくなってきて，無視できなくなっていることを示 している.

$Q=400$ (第 9 図) では，各 $H$ とも，分布の幅がら に広がっている.ここで特徵的なのは，H=2.5，5 の正のピークの分布には $W \approx-2$ 付近にくびれが見ら れ，正側と真側にそれぞれ山が存在するととである. $H=5$ の場合には，W<0 の正のピークの存在確率か

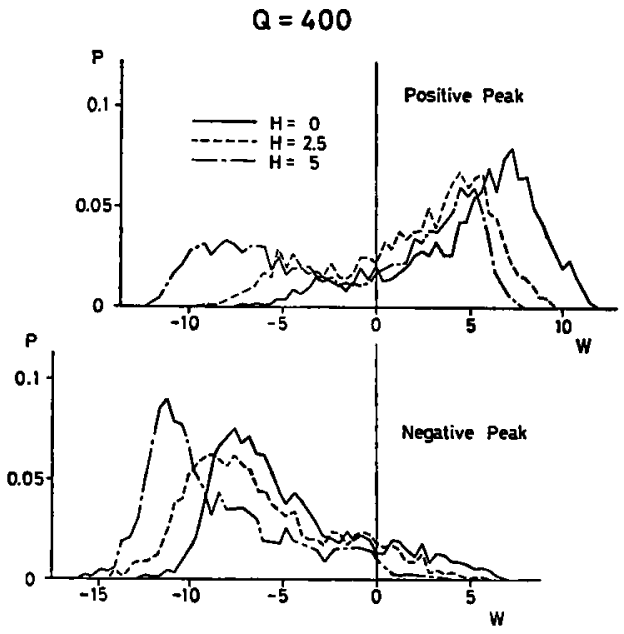

第 9 図中央点变位 $W$ のピークの確淬密度関数 (PDF) $Q=400$ の場合

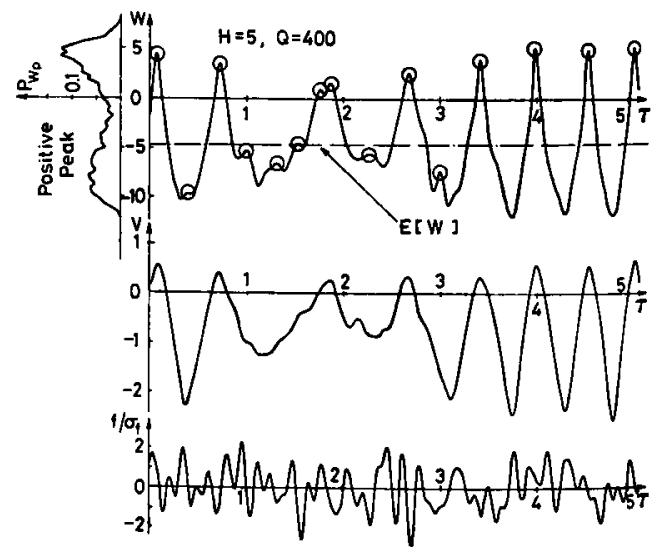

第 10 目 $Q=400, H=5$ の場合のランダム加振力 $f$ と芯答 $W$ およびVの履歷の 1 例 ○印は $W$ の正のピークを示す. 
$W>0$ の正のピークの存在確率とほほ同じになってい ろ. 負のピークの PDF ああわせて考えると，一見,

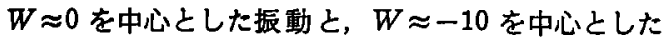
振動が存在するように見える。このような PDF が得 られる理由を説明するため，Wおよび変位体皘 $V(=$ $\left.\int_{0}^{1}[w(\xi, t) / h] \xi d \xi\right)$ の履歴の 1 例をランダム加振波之

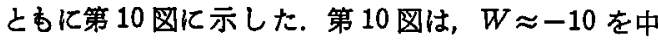
心とした振動か子存在するのではなく，変形形状の変化 に伴う中央点の変位の逆転に起因して $W<-2$ の領 域にW の正のピークが現れるととを示している．さ らに振幅が非常に大きくなると(第 10 図 $\tau>3$ 参)， 上記のような変形形状の変化化うピークはほとんど 現れなくなるととを示している． $H=2.5$ の場合は， $W<0$ の領域化正のピークが存在する確率が $Q=400$ の場合のほうが $Q=100$ の場合よりあ小さくなってい る. これは第 10 㘡から推洌すると， $Q=100$ の場合は $\tau<3$ の型の履歷が存在する確率かかかり大きいのに 対し， $Q=400$ では振幅が大きくなって $\tau>3$ の型の蕧 歴加支配的になっているためと考えられる．第 9 図の $H=2.5$ の PDF の分布形状は，横方向に 2.5 平行移 動すると， $H=0$ の PDF の分布形状と大局的には一 致しており，その振動特性は平板に近くなっていると 考えられる. 負のピークの PDF の分布形状は， $H=$ 2.5 では $H=0$ と大差なくなり, てれからも $H=2.5$ では平板的な挙動をしていると考えられる． $H=5$ て は，上述の $W<0$ の領域の正のピークとの関連で若 千分布形状に差が見られる. PDF が最大となるWの 值は， $H=0$ では約 -7.5 に対，し， $H=2.5$ では約 $-9.0 \approx-7.5-H, H=5$ では約 $-11.5 \approx-7.5-H$ の関係が見られ，大局的には平板の振動に近ついてい ると考えられる。

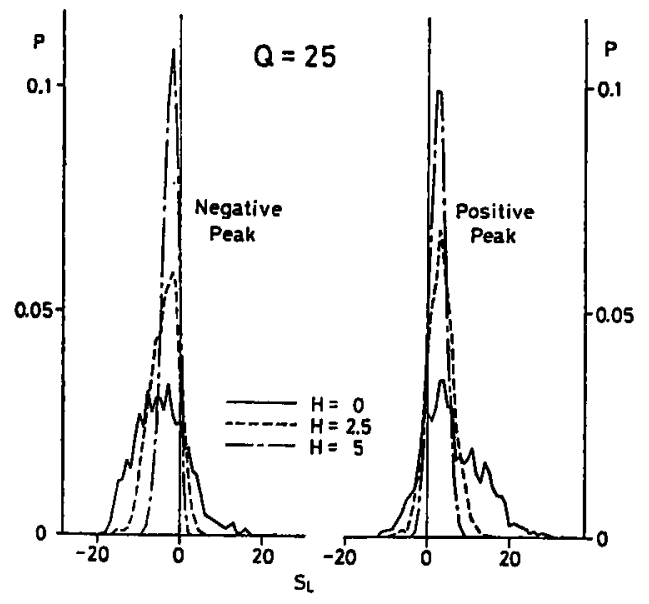

第11四 下面店力 $S_{\mathrm{L}}$ のピークの確率密度関数 $Q=25$ の埸合
$S_{\mathrm{U}}, S_{\mathrm{L}}$ のピークの PDF について考察する. $Q=25$ （第11図）では，まだ中央面の伸び縮みによって生ず る非線形項の影掣が小さいので， $H=2.5 ， 5$ につい $\tau S_{\mathrm{U}}, S_{\mathbf{L}}$ とあに正のピークの分布と負のピークの分 布とは，原点を中心に互いにほぼ対称の関係にある. また， $H$ が大きいほど分布が狭いので，曲率をつけた 勃果があることがわかる. $S_{\mathrm{U}}$ の分布と $S_{\mathrm{L}}$ の分布之 の差は小さく分布幅は $S_{\mathrm{L}}$ のほうが大きいので $S_{\mathrm{U}}$ の 罒は省略した。

$$
Q=100
$$
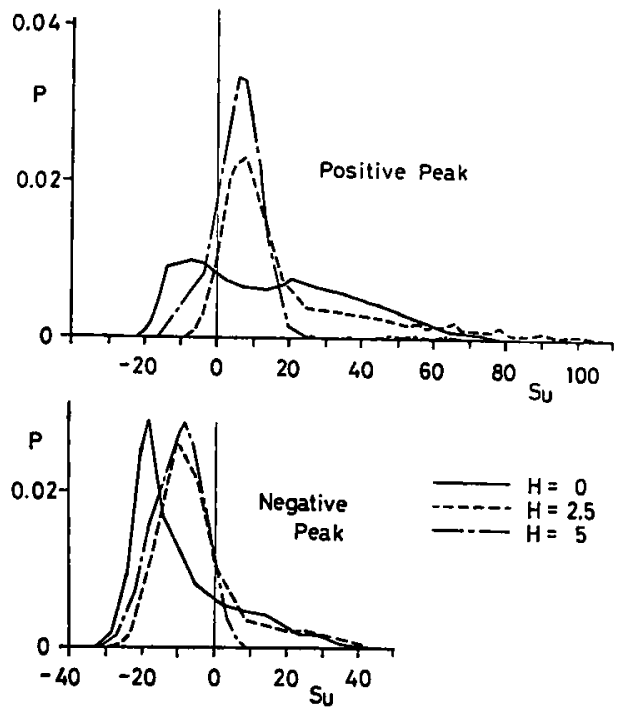

第12図上面応力 $S_{\mathrm{U}}$ のビークの確率密度関数 (PDF) $Q=100$ の場合

$$
Q=100
$$
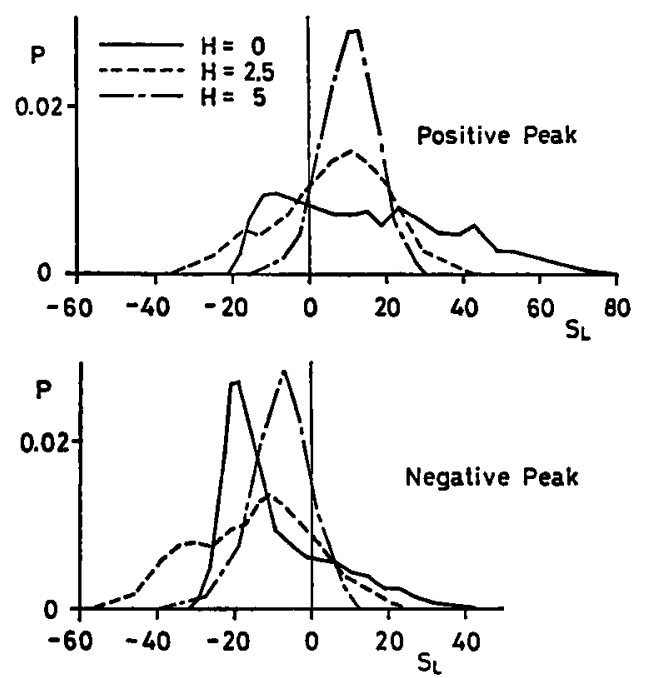

第 13 区 下面応力 $S_{\mathrm{L}}$ のピークの確率密度関数 (PDF) $Q=100$ の場合 
$Q=100$ (第 12,13 図) では，上記非線形項の影帮が はっきり現れている， $H=0$ の場合，曲げによる王縮 が中央面の伸びによって打ち消され，逆側では曲げ による伸びに中央面の伸びが加わってさらに大きくな り，正のピーク，負のピークとともに正方向に裾を引 くようになる、しかし，曲率がついていると，振動が 大きくなるに伴い正の側と負の側との振動形状の差が 大きくなるために, $S_{\mathrm{U}}$ と $S_{\mathrm{L}}$ の分布に差が見られるよ うになる. また $W<0$ 側への振幅が大きくなり，W <0のピークに対応する曲げ応力が大きくなって（第 5 図参照)， $S_{\mathrm{L}}$ の分布は王縮側すなわち負側に伸びて いくととになる.この様子は $H=2.5$ に顕著に現れて いる.

$Q=400$ (第 14, 15 図) では, 上記非線形項の影響か， $H=2.5,5$ にあ現れ， $S_{\mathrm{U}}$ の正のピークが正の方向へ
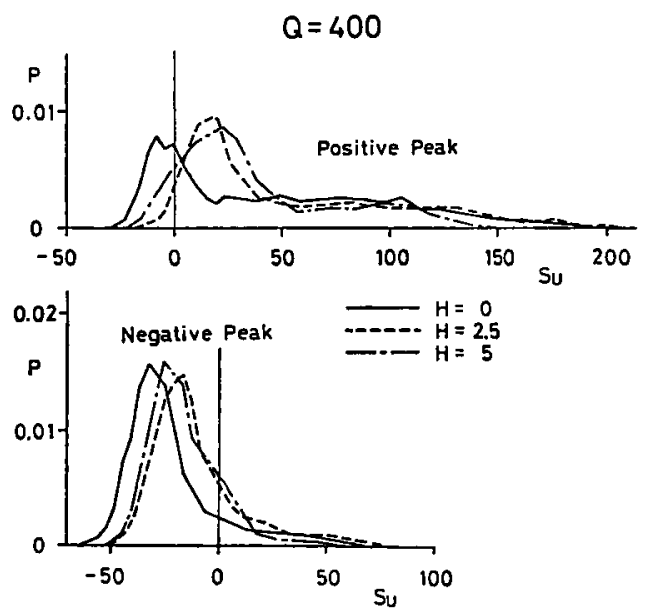

第 14 図上面応力 $S_{\mathrm{U}}$ のピークの確率密度関数 (PDF) $Q=400$ の場合

$Q=400$

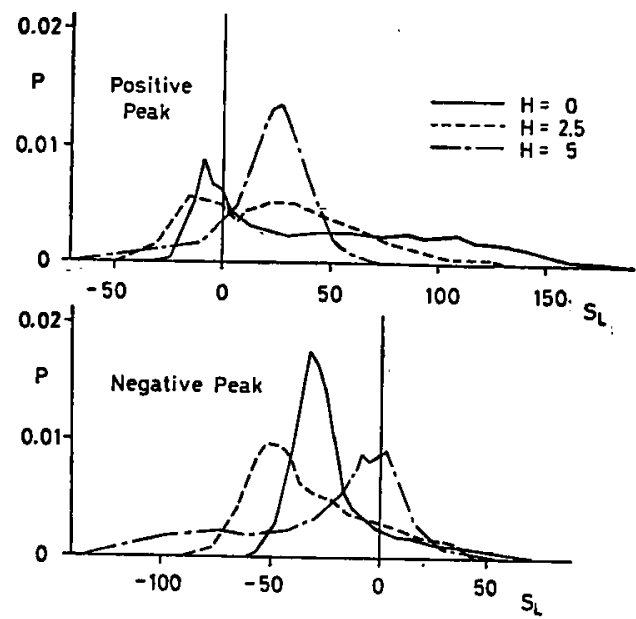

第 15 涩下面応力 $S_{\mathrm{L}}$ のピークの硫率密度関数 (PDF) $Q=400$ の場合
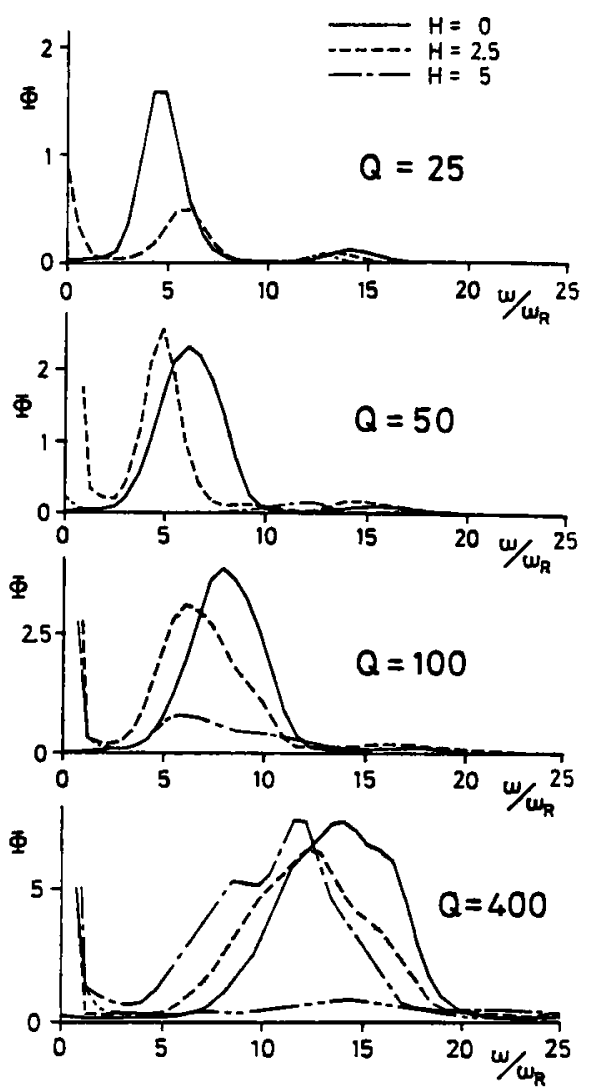

第 16 図中央点変位 $W$ のパワースペクトル密度 (PSD)

裾をひいており，負のピークの分布形状は $H=0$, 2.5. 5 の三つともよく似ている. $S_{\mathrm{L}}$ では， $H=5$ の 場合に，W<0の方向への振動に伴って発生する大き な曲げ応力の影幚で負の大きな応力を生じている.

第 3 表と第 11〜15 図を比较して，飛び移りを含ん でガウス分布からかなりはずれた上記のような $S U$ ， $S_{\text {L }}$ の振動特性を論ずるには. mean と SD とでは不十 分で, $S_{\mathrm{U}}, S_{\mathrm{L}}$ のピーク（または $S_{\mathrm{U}}, S_{\mathrm{L}}$ ) の PDF を必 要とすると考えられる.

次に，WのPSD について述べる（第 16 図），Q= 25 の場合， $H=0$ にくらへ $H=2.5$ の振動は小さく， $H=5$ の振動はさらに小さくなっている. $H=0$ の PSD のピークは二つ見られるが，それぞれ 1 次および 2 次の固有振動数より少し高い所に位置している. れに対し， $H=2.5$ の低いほうのピークおよひ $H=5$ のピークはそれそれれの 1 次の固有振動数より少し低い ところに存在している，Q=50になると，各 1 次のピ ーク, とくに $H=2.5$ のピークは大きくなり， $H=0$ の 1 次のピークはさらに振動数の高いほうへ移り，H =2.5 および $H=5$ の 1 次のピークは低いはうへと移 る. このことから, $H=0$ の1次ではハードニングの 現象が, $H=2.5$ の 1 次では強いソフトニング, $H=5$ 
の 1 次では弱いソフトニングの現象がおてっているて とがわかる，Q=100になると，H=2.5 の殸は振動 が大きくなったゆえにハードニングの特性が付け加わ って，PSD の山の幅す広がり，振動が複雑になって きたことがわかる，H=5 の殻はあきらかに強いッフ トニングの性質を示している，Q=400 になると， $H$ $=2.5$ の殻は強いハードニングを示し， $H=5$ の殼は， $Q=100$ のときの $H=2.5$ の款と同様にハードニング の特性加付け加わり， $H=2.5,5$ ともに山の幅が広 くなって $H=0$ の分布に近ついている.これは，大き な外力によって殸が飛び移りながら大振幅で振動する 場合には曲率をつけたととの勃果が小さくなり，平板 の振動に似てくるととを示すすのと考えられる.

\section{5. 疲労寿命の推定}

前䬣で得られた応力のピーク履歴から疲労寿命を推 定し，QとHの疲労寿命に与える影響を調へる.

S-N 曲線は末益 ${ }^{8}$ が片持架の疲労実験により求めた ののを用いる(第 17 図)，本解析では応答応力を弾性 で計算することを考虑して，末益”が片持梁の $2024 \mathrm{~T}$

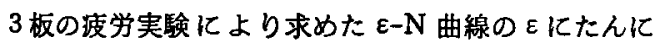
弾性係数 $E /\left(1-\nu^{2}\right)$ を挂けた $\mathrm{S}-\mathrm{N}$ 曲線を用いる（第 17 図実線)．さらに材料の疲労特性は塑性域まで含め てはほ $\varepsilon-\mathrm{N}$ 曲線で表されると仮定して，低サイクル の部分は目の破線のように外㨉した。

ランダムな応力履歴の累皘損傷度の計算は文献7)の 方法によった。すなわち、ひとつの極大値と隣りの極小 値(または極小值と隣りの極大値) との二つの值加ら計 算される平均応力 $S_{\mathrm{M}}$ と応力振幅 $S_{\mathrm{A}}$ 加 万相当応力 $S_{\text {。 }}$

$$
\begin{gathered}
S_{\mathrm{a}}=S_{\mathrm{A}}\left\{1-\kappa\left(S_{\mathrm{M}} / S_{\mathrm{tu}}\right)^{r}\right\}^{-1} \\
\kappa=1.385, \quad \gamma=0.923
\end{gathered}
$$

を求め，乙れを線形䇣積損賃則にあてはめて単位時間 あたりの疲労損傷度 $D_{\mathrm{m}}$ の期待値 $E\left[D_{\mathrm{m}}\right]$ を計算し， その逆数として疲労寿命を算出した。 ここで $S_{\text {tu }}$ は材 料の引張破断応力, $\kappa, r$ は両端固定梁の疲学実験結 果帛加ら定めた值である.

以上のようにして求められた疲労寿命を第 4 表に示 す. 表中心とあるのは，累積損傷が小さすぎて計算機 の中で under flow をおとしたので寿命を無限大とし たものである.

$Q=25$ では $H=0$ のみ寿命が算出されている. $Q=$ 50 亿なると $H=2.5$ の寿命む算出され，Q=100では $H=2.5$ の $S \mathrm{U}$ における疲労寿命が $H=0$ よりもかな り短くなり， $H=5$ の寿命も $H=0$ の寿命の 100 倍程 度まで接近している. $Q=200$ です $H=2.5$ の $S_{\mathrm{U}}$ に おりる寿命加最も短いか， $H=0,2.5,5$ の寿命は非 常に接近している. $Q=400$ で $H=10$ の寿命が急に

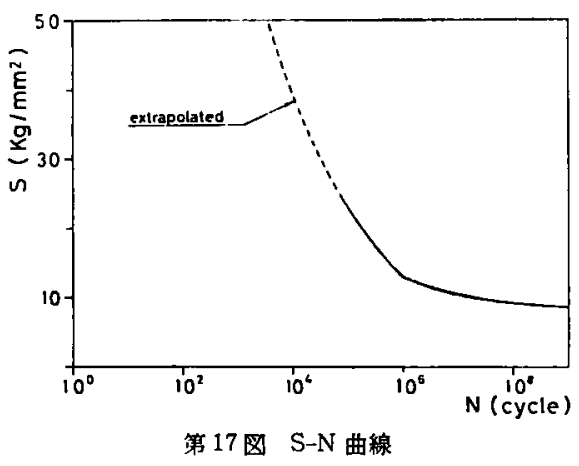

第 4 表 疲 労 寿 命

\begin{tabular}{|c|c|c|c|c|}
\hline \multirow{2}{*}{$Q$} & \multicolumn{4}{|c|}{$H$} \\
\hline & 0 & 2.5 & 5 & 10 \\
\hline \multirow{2}{*}{25} & $1.08_{+23}$ & $\infty$ & $\infty$ & $\infty$ \\
\hline & 4. $77_{+23}$ & $\infty$ & $\infty$ & $\infty$ \\
\hline \multirow{2}{*}{50} & $7.92_{+18}$ & 2. $60_{+17}$ & $\infty$ & $\infty$ \\
\hline & $2.12+14$ & 4. $37_{+18}$ & 1. $58_{+28}$ & $\infty$ \\
\hline \multirow{2}{*}{100} & 1. $30_{+\infty}$ & 7. $54_{+\iota}$ & $1.52+\mathrm{e}$ & $\infty$ \\
\hline & $2.04+$ & $2.06_{+\bullet}$ & 1. $15_{+10}$ & $\infty$ \\
\hline \multirow{2}{*}{200} & 9. $28_{+}$s & 3. $58_{+3}$ & 6. $58_{+4}$ & 8. $96+1$, \\
\hline & $7.50_{+3}$ & 1. $21_{+\mathrm{s}}$ & 1. $75_{+\mathrm{s}}$ & 2. $79_{+11}$ \\
\hline \multirow{2}{*}{400} & 4. $71_{+2}$ & 3. $52+2$ & 2. $65_{+3}$ & 1. $86_{+3}$ \\
\hline & 5. $42_{+2}$ & 3. $81_{+}$, & 3. $73_{+3}$ & 4. 51 \\
\hline
\end{tabular}

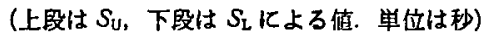

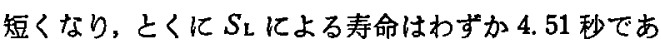
る. ただし， $H=10$ の殼に関しては前に述べたように 3 自由度近仪では不十分と考えられるので，他の $H$ 之 直接比較するのは無理であろう. $H=10$ を除くと,や はり $H=2.5$ の $S_{\mathrm{U}}$ による寿命がわずかではあるが $H=0$ の寿命より短い.

ところで疲労寿命と $S_{\mathrm{U}}$ の平均値などとの関係につ

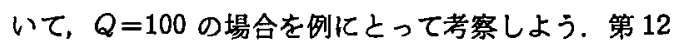
四に示された $S_{\mathrm{U}}$ の正のピーク分布を見ると，正の倒 に裙野がのびて，本計算で得られた最大応力が $H=0$ では約 84，H=2.5 では約 106 になっている．乙のこ とから $H=2.5$ の寿命は $H=0$ の寿命の約 $1 / 17$ にな っていることが理解される. また $H=5$ の分布は, 確 率は小さいが飛移りにより大きな応力か発生しその最 大値は 70 程度に達することを示しており，てれによ り寿命が $1.5 \times 10^{8}$ 秒程度に下がったことが理解され る. このような結果は，第 3 表の $S_{\mathrm{U}}$ の mean と SD を見る限りは理解されず，飛び移りを含む問題では， $S_{\mathrm{U}}$ のピーク（または $S_{\mathrm{U}}$ ）の分布関数で議論しなけれ ばならないととを示している.

$H=5$ については， 3 自由度近似で振幅が非常に大 きくなった場合，固定端部の曲げ応力を小さぬに評価 
する傾向があるので, 疲労寿命を長めに算出すると考 えられる. したがって $Q=400 の S_{\mathrm{U}}$ の場合に $H=5$ の寿命がとくに長いのは，との理由によると考えられ る.

\section{6. 結}

論

本論文において，浅い球形殼の変形を固有振動モー ドで展開して，まず静的平衡特性を求め，次いでシミ ュレーション法によりランダム振動応答を計算し疲労 寿命を推定した．それらの結果から次の結論が得られ たすのと若えられる.

1) $H=5$ までの殻では，固有振動モードを用いて 3 自由度近似で求めた静的平衡特性は従来のあの とよく一致する.

2) 飛び移りを伴って振動する場合，W<0の預域 に正のピークが生じ，W<0の正のピークの分布 が $W>0$ の領域の分布と同程度となり，飛び移り 先で傲小振動を起こしているかのように見えるか とれは飛び移り先で変形形状が変化することによ るものである.

3）振動が非常に大きくなって飛び移り先をはるか に越えて振動するようになった場合，WのPDF およひ PSD は平板の場合に類似しており，振動 特性が平板に近くなる。

4) 音氏が小さい場合は，曲率の効果が大きく，疲 労寿命は長くなるが, 音暗疲労が問題となる高音 圧では，飛び移り座届を伴うので，曲率をつけた ことにより逆に平板よりも疲労寿命が短くなるこ とがある゙?.

5）飛び移りを伴う場合，応力の平均値と標準偏差 だけから寿命を推定するととはできず，応力また はそのピークの PDF で判断する必要がある.
$H=10$ の場合については少なくとす 5 自由度以上 で計算する必要があるので本論文では，W， $S_{\mathrm{U}}$ など の分布の図示は省略した. 十分な精度で計算しその特 性を論ずるのは今後の課題としたい.

\section{参考文献}

1) 小林繁夫, 喏原太郎：浅い役のランダム加振に対する 非楾形応答, CAS 研究報告, 第 17 号 (1974.3), pp. 113-130.

2) 末益博志，小林繁夫 : 浅い円筒形曲面パネルの外圧に よる座屈と非線形ランダム振動応答の解析 I. 非線形 振動方程式と外圧による座届, 日本航空宇宙学会誌, 第29巻, 第328号 (1981.5), pp. 260-267.

3) Keller, H. B. and Wolfe, A.: On the Nonunique Equilibrium States and Buckling Mechanism of Spherical Shells, J. Soc. Ind. Appl. Math., Vol. 13 (1965), p. 674.

4) Budiansky, B. : Buckling of Clamped Shallow Spherical Shells, Proceedings of the IUTAM Symposium on the Theory of Thin Elastic Shells, Delft, Holand (1959).

5) Weinitschre, H. J. : On the Stability Problem for Shallow Spherical Shells, J. Math. Phys., Vol. 38 (1960), p. 209.

6) Thurston, G. A. : A Numerical Solution of the Nonlinear Equations for Axisymmetric Bending of Shallow Spherical Shells, J. Appl. Mech., Vol. 28 (1961), p. 557.

7）小林繁夫，末益博志：シミュレーション法による周边 単純支持矩形板の韭線形ランダム振動応答解析，日本 航空宇宙学会誌, 第26巻, 第291号 (1978. 4), pp. 206214.

8）末益博志：パネルの音瑟疲学問題に関する基礎研究， 東京大学大学院工学系研究科航空学専門䛊程学位論文 (1979. 12)

9) 末益博志，小林䇣夫：浅い円筒形曲面パネルの外王に よろ坐届と非線形ランダム振動灾答の解析 II. 非線 形ランダム振動応答, 日本航空宇宙学会誌, 第29巻, 第328号 (1981.5), pp. 268-274. 